Jurdimas (Jurnal Pengabdian Kepada Masyarakat) Royal

Vol. 4 No. 2, Mei 2021, hlm. 141 - 146

Available online at https://jurnal.stmikroyal.ac.id/index.php/jurdimas

\title{
PELATIHAN PEMBUATAN KERIPIK DAUN KOPI DI DESA CUGUNG LALANG KECAMATAN KEPAHIANG KABUPATEN KEPAHIANG
}

\author{
Mety Herlina $^{1}$, Jayanti Syahfitri ${ }^{1}{ }^{*}$, Rukiah Lubis $^{1}$, Endang Sulaiman $^{1}{ }^{1}$ Nopryeni $^{1}$ \\ ${ }^{1}$ Pendidikan Biologi, Universitas Muhammadiyah Bengkulu \\ Email: *jayanti_syahfitri@yahoo.co.id
}

\begin{abstract}
So far the coffee commodity is still known as the main ingredient in the manufacture of beverages, namely coffee. Apart from coffee beans, many people in Cugung Lalang Village still do not know the information coffee waste can be used in their daily lives. Some examples of the use of coffee waste can be used as compost, besides that coffee leaves can be made into a type of food, namely coffee leaf chips. In general, coffee farmers will routinely maintain postharvest coffee gardens, namely by trimming coffee leaves. The coffee leaf waste resulting from pruning will only be piled up and left on the plantation. Therefore, this training can be an innovation that can increase the knowledge, skills and independence of community members in entrepreneurship. This of course will support the opening of opportunities to improve the economic level of the community. The results of the training showed that the community was able to make coffee leaf chips. The need for further training on how to package processed coffee leaf chips, so that they are ready to be marketed
\end{abstract}

Keywords: coffee leaf chips; training

\begin{abstract}
Abstrak: Sejauh ini komoditas kopi masih dikenal sebagai bahan utama dalam pembuatan minuman yaitu kopi. Selain biji kopi masyarakat di Desa Cugung Lalang masih banyak yang belum tahu mengenai informasi bahwa limbah kopipun dapat dimanfaatkan dalam kehidupan sehari-hari. Beberapa contoh pemanfaatan limbah kopi yaitu dapat digunakan sebagai pupuk kompos, selain itu daun kopi dapat dibuat jenis makanan yaitu keripik daun kopi. Pada umumnya para petani kopi akan rutin melakukan perawatan kebun pascapanen kopi yaitu dengan melakukan pemangkasan daun kopi. Limbah daun kopi hasil dari pemangkasan ini hanya akan ditumpuk dan dibiarkan di perkebunan. Oleh karena itu, adanya pelatihan ini dapat menjadi suatu inovasi yang dapat meningkatan pengetahuan, keterampilan dan kemandirian warga masyarakat dalam berwirausaha. Hal ini tentunya akan mendukung terbukanya peluang untuk meningkatkan taraf perekonomian masyarakat. Adapun metode yang digunakan yaitu melalui kegiatan sosialisasi dan pelatihan. Hasil dari pelatihan menunjukan bahwa masyarakat mampu membuat olahan keripik daun kopi. Perlunya pelatihan lanjutan mengenai bagiamana pengemasan olahan keripik daun kopi, sehingga siap untuk dipasarkan.
\end{abstract}

Kata kunci: keripik daun kopi; pelatihan 
Jurdimas (Jurnal Pengabdian Kepada Masyarakat) Royal

Vol. 4 No. 2, Mei 2021, hlm. 141 - 146

ISSN 2614-7912 (Print)

DOI: https://doi.org/10.33330/jurdimas.v4i2.954

ISSN 2622-3813 (Online)

Available online at https://jurnal.stmikroyal.ac.id/index.php/jurdimas

\section{PENDAHULUAN}

Pemeliharaan tanaman kopi yang dapat dilakukan oleh petani, salah satunya yaitu dengan melakukan pemangkasan. Pemangkasan ini merupakan kegiatan yang dilakukan dalam rangka pemeliharaan, peremajaan, dan pemangkasan pohon pelindung. Pada umumnya masyarakat petani kopi hanya melakukan pemangkasan guna pemeliharaan saja, dimana pemangkasan dilakukan terhadap daun kopi atau tunas yang tidak dikehendaki. selanjutnya hasil pemangkasan pemeliharaan ini belum dimanfaatkan secara optimal (Pudji, \& Harta, 2015)

Masyarakat pada umumnya hanya mengenal tanaman kopi sebagai penghasil biji kopi yang merupakan bahan dasar pembuatan kopi. Tanaman kopi dianggap sebagai tanaman dengan komersialnya yaitu pengolahan biji kopi menjadi bahan minuman seduh kopi. Sementara itu daun kopi mayoritas belum banyak dimanfaatkan oleh masyarakat, sehingga daun kopi masih dianggap sebagai limbah. Masyarakat belum banyak mengetahui bahwa daun kopi dapat dimanfaatkan sebagai produk pangan (Pristiana, Susanti, \& Nurwantoro, 2017).

Diketahui bahwa para petani kopi di desa Cugung Lalang hanya fokus pada hasil perkebunan yaitu butir kopi yang telah masak. Setiap musim panen tiba para petani akan memetik butir kopi yang telah memerah, sedangkan daunnya masih dianggap tidak bermanfaat. Sejauh ini pemanfaatan limbah dari tanaman kopi masih sebatas pembuatan pupuk kompos, sedangkan pemanfaatan daun kopi masih belum dilakukan oleh masyarakat. Hal ini tidak terlepas dari masih kurang (minimnya) pengetahuan dan informasi serta keterampilan yang dimiliki masyarakat. Sejalan dengan ungkapan (Siringoringo, Lubis, \& Nainggolan, 2012) bahwa selama ini daun kopi yang berasal dari pemangkasan akan dibuang begitu saja, belum ada pemanfaatanya secara lanjut. Daun kopi dapat dimanfaatkan menjadi bahan dasar dalam pembuatan jenis makanan atau minuman, karena daun kopi banyak mengandung kadar tanin. Selain itu daun kopi memiliki aroma dan rasa yang tidak akalah nikmat dengan daun kopi.

Pemanfaatan limbah daun kopi telah dilakukan oleh baberapa peneliti terdahulu, diantaranya yaitu (Ayunillah \& Suharso, 2014); (Khotimah, 2014) dalam penelitiannya telah melakukan pemanfaatan daun kopi sebagai bahan pembuatan kopi kawa.

(Mayasari, \& Ani, 2016) mengungkapkan bahwa besar kemungkinan para pecinta kopi hanya tahu tentang nikmatnya olahan biji kopi saja, tanpa terpikir bahwa selain bijinya, limbah daun kopi yang merupakan hasil pemangkasan juga dapat dimanfaatkan sebagai bahan dalam pembuatan camilan yaitu kerupuk daun kopi yang memiliki banyak khasiat karena mengandung antioksidan, selain itu daun kopi juga mengandung bahan kimia yang disebut mangiferin.

Selama ini pemanfaatan daun kopi telah digunakan baik secara alami maupun tradisional dalam berbagai pengobatan. Hal ini disebabkan karena pada daun kopi terdapat sifat kesehatan yang menguntungkan diantara lain yaitu sebagai obat diuretik, antimikroba dan aktivitas antioksidan. Beberapa senyawa yang terkandung dalam daun kopi, diantaranya yaitu alkaloid, senyawa fenolik, karbohidrat, protein dan saponin (Hasanah, Maharani, \& Munarsih, 2017). 
Jurdimas (Jurnal Pengabdian Kepada Masyarakat) Royal

Vol. 4 No. 2, Mei 2021, hlm. 141 - 146

DOI: https://doi.org/10.33330/jurdimas.v4i2.954

ISSN 2622-3813 (Online)

Available online at https://jurnal.stmikroyal.ac.id/index.php/jurdimas

\section{METODE}

Sosialisasi penyuluhan dilakukan di Balai Desa Cugung Lalang. Kegiatan ini diikuti oleh seluruh warga desa Cugung Lalang. Setelah sosialisasi dilanjutkan dengan pelatihan pembuatan keripik daun kopi. Kegiatan pelaksanaan sosialisasi dan pelatihan ini diawali dengan adanya persiapan dan koordinasi pelaksanaan kegiatan dengan masyarakat setempat. Pada tahap ini mengkaji atau menganalisis permasalahan yang dihadapi (analisis kebutuhan). Selanjutnya proses pelaksanaan sosialisasi dan pelatihan, monitoring dan evaluasi.

Pada tahap pelaksanaan dilakukan kegiatan yang berupa sosialisasi tentang pemanfaatan limbah daun kopi hasil pemangkasan, sehingga masyarakat tahu bahwa tidak hanya biji kopi yang dapat dimanfaatkan melainkan daunnya juga dapat menjadi bahan dasar pembuatan keripik. Selain itu juga sosialisasi tentang manfaat yang terkadung dalam daun kopi. Kegiatan sosialisasi diikuti dengan adanya kegiatan pelatihan pembuatan keripik daun kopi. Masyarakat dilatih dengan ikut serta mempraktikan langsung bagaimana cara mengolah daun kopi menjadi keripik. Pada saat pelaksanaan sosialisasi dan pelatihan juga dilakukan pendampingan dan mentoring yang bertujuan untuk membantu masyarakat yang masih kesulitan dalam mengolah daun kopi, sehingga pada saat ini masyarakat dapat langsung berkonsultasi dengan prakarya. Dengan keterampilan yang diperoleh masyarakat diharapkan mampu melanjutkan program ini dalam bentuk mewujudkannya sebagai salah satu peluang bisnis. Selain itu masyarakat juga diharapkan mampu melatih keterampilan yang telah dimiliki dengan melakukan pelatihan kembali ke masyarakat lain.
Prosedur pelaksanaan sosialisasi dan pelatihan tersebut antara lain:

1) Sosialisasi tentang kandungan dan manfaat daun kopi sebagai bahan dasar pembuatan keripik;

2) Pelatihan - pelatihan pembuatan keripik daun kopi (: mempersiapkan bahan dan alat yang diperlukan, memilah daun kopi yang muda, membuat adonan, dan menggoreng daun kopi yang sudah dicelupkan dalam adonan);

3) Pelatihan dalam pengemasan produk.

Target dari program ini yaitu :

1) Meningkatkan pengetahuan, wawasan, dan keterampilan dalam memanfaatkan dan mengolah daun kopi menjadi keripik/kerupuk.

2) Mengurangi limbah kulit kopi dan daun kopi muda yang ada di perkebunan warga

3) Meningkatkan kreatifitas warga di Desa Cugung Lalang

4) Membuka peluang usaha di Desa Cugung Lalang, sehingga dapat meningkatkan kesejahteraaan dalam perekonomian

5) Membuat produk kripik daun kopi secara mandiri dengan memanfaatkan daun kopi yang masih muda untuk menjadi sebuah kripik, yang ada disekitar perkebunan

\section{PEMBAHASAN}

Pelaksanaan kegiatan pengabdian ini meliputi beberapa tahap, diantaranya yaitu kegiatan sosialisasi, pelatihan, pendampingan (mentoring) dan evaluasi.

Kegiatan sosialisasi diawali dengan pemaparan materi tentang manfaat dan kopi, kandungan daun kopi, dan olahan apa saja yang dapat dihasilkan dengan bahan dasar daun kopi. 
Available online at https://jurnal.stmikroyal.ac.id/index.php/jurdimas

Pada tahap ini bertujuan agar dapat memberikan pemahaman kepada masyarakat tentang pemanfaatan limbah daun kopi. Sosialisasi pembuatan Kripik Daun kopi merupakan kegiatan yang bermanfaat dilakukan di lingkungan masyarakat. Harapan dari kegiatan ini agar warga desa dapat memanfaatkan daun kopi yang masih muda hasil dari limbah pemangkasan perkebunan untuk dihasilkan menjadi kripik. Pembuatan Kripik daun kopi sangat ideal dan memungkinkan untuk dilakukan secara mandiri. Hal ini merupakan sarana dalam menumbuhkan dan meningkatkan kemandirian dan jiwa kewirausahaan di lingkungan pedesaan.

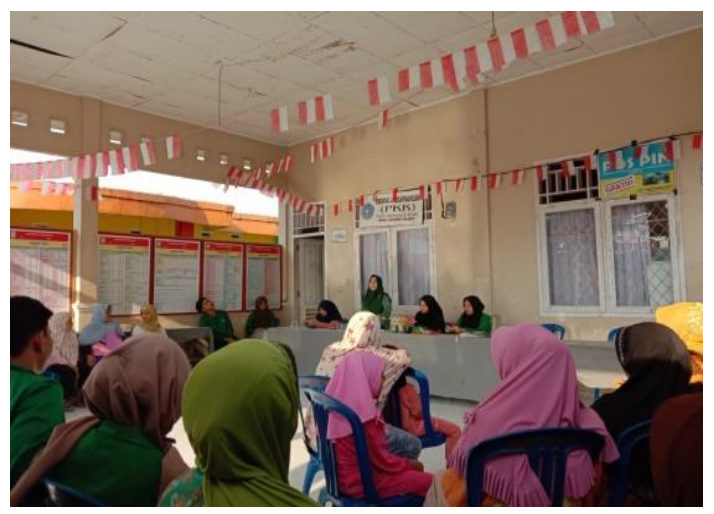

Gambar 1. Kegiatan Sosialisasi

Pada tahap pelaksanaan kegiatan pelatihan, semua anggota tim bekerja sama dalam menyampaikan atau menjelaskan materi dan langkah kerja dalam pembuatan keripik daun kopi kepada semua masyarakat yang hadir. Tim menjelaskan berbagai peralatan dan bahan yang dibutuhkan (tergolong mudah). Selain itu, pembuatannya sederhana dan biaya yang dibutuhkan murah. Hal tersebutlah tentu sangat medukung efisisiensi dalam terlaksananya kegiatan sosialisasi serta pelatihan pembuatan keripik daun kopi.
Dengan demikian kegiatan ini dapat menjadi solusi dalam mengatasi salah satu limbah yang dihasilka pada saat pemangkasan daun kopi di perkebunan setiap kali adanya perawatan kebun pascapanen. Daun kopi yang sudah tua dan menguning akan dipangkas dan ditumpuk di kebun. Sisa pangkasan ini hanya dibiarkan saja dan tidak dimanfaatkan. Sisa pangkasan kulit kopi bisa dibuat kompos dan digunakan untuk memupuk tanaman.

Pada saat kegiatan pelatihan dan pendampingan praktik berlangsung terlihat bahwa semua warga sangat antusias mengkuti kegiatan. Hal ini terlihat dari keikutsertaan warga pada saat turun tangan melakukan praktik pembuatan keripik. Warga desa Cugung Lalang sangat aktif bertanya setiap langkah yang dilakukan. Mereka seolah tidak mau ketinggalan informasi terkait langkah pembuatan keripik daun kopi. Semua warga desa Cugung Lalang mengaku bahwa informasi tentang pembuatan keripik ini masih menjadi hal baru bagi mereka, sehingga sosialisasi dan pelathan ini sangat bermanfaat da diperlukan.

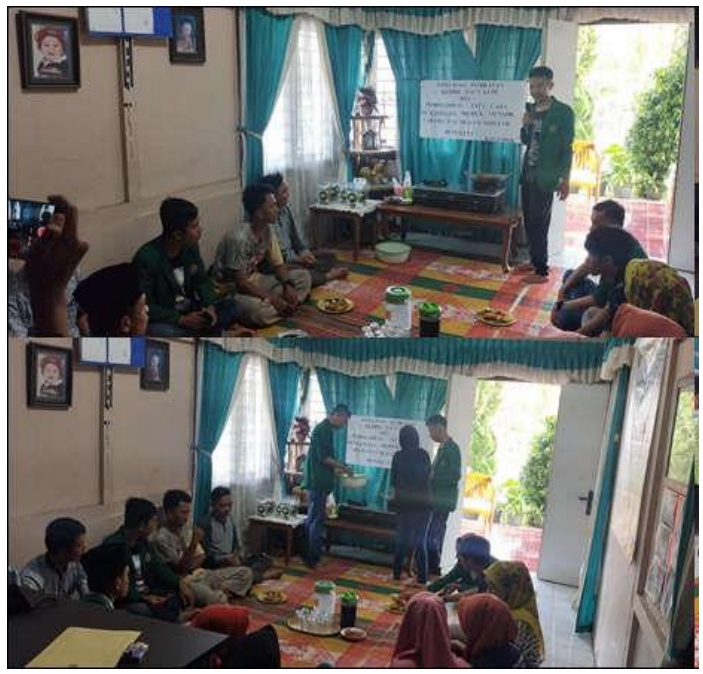

Gambar 2. Kegiatan Pelatihan 


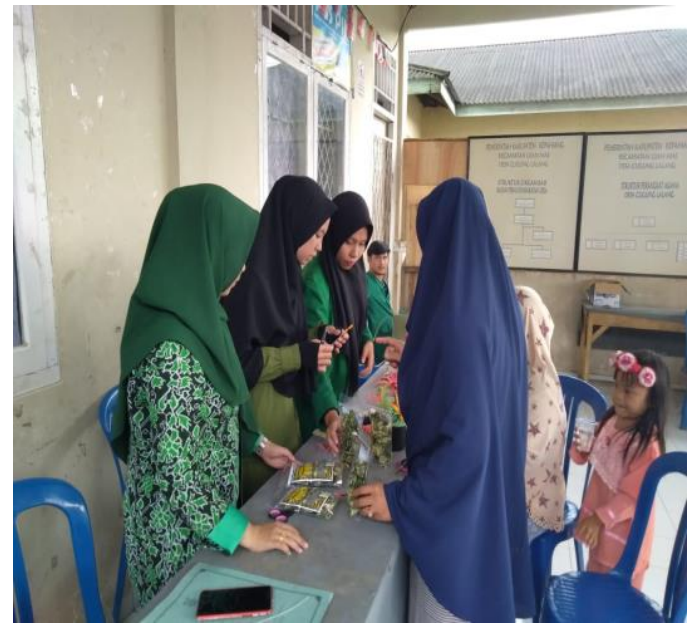

Gambar 3. Pendampingan dalam pengemasan produk Olahan

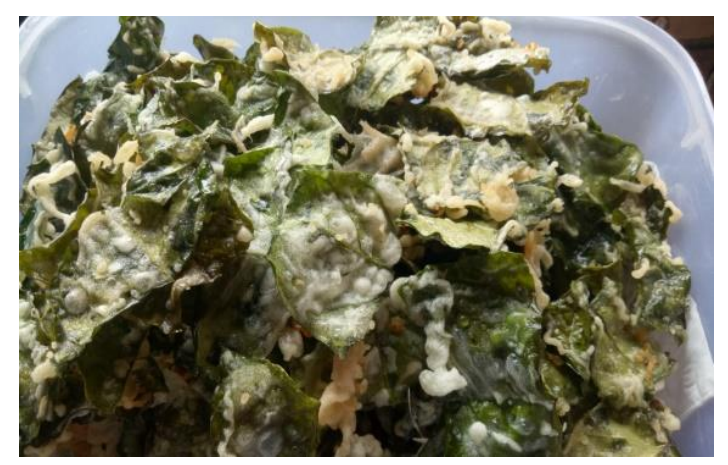

Gambar 4. Keripik Daun Kopi

\section{KESIMPULAN}

Sosialisasi dan pelatihan pembuatan keripik daun kopi merupakan kegiatan yang penting dan bermanfaat dilakukan di lingkungan masyarakat. Harapan dari kegiatan ini agar warga desa dapat memanfaatkan daun kopi. Hal ini merupakan sarana dalam menumbuhkan dan meningkatkan kemandirian dan jiwa kewirausahaan di lingkungan pedesaan. Selain itu adanya kegiatan ini dapat menjadi solusi bagi masyarakat dalam mengurangi limbah daun kopi hasil dari pemangkasan perkebunan.

\section{UCAPAN TERIMA KASIH}

Melalui tulisan ini penulis mengucapkan terima kasih kepada Universitas Muhammadiyah Bengkulu, khususnya LPPM UnMuh Bengkulu, yang telah menyuport pelaksanaan kegiatan pengabdian ini. Selain itu terima kasih pada semua tim pengabdian dan masyarakat Desa Cugung Lalang yang telah berpartisipasi pada kegiatan ini sampai dengan selesai.

\section{DAFTAR PUSTAKA}

Ayunillah, N. R., \& Suharso, P. (2014). Pemberdayaan Ibu Rumah Tangga Melalui Pengolahan Daun Kopi Kawa Di Desa Harjomulyo Kecamatan Silo Kabupaten Jember. 125-139.

Pristiana, D. Y., Susanti, S., \& Nurwantoro, N. (2017). Aktivitas Antioksidan Dan Kadar Fenol Berbagai Ekstrak Daun Kopi (Coffea sp.): Potensi Aplikasi Bahan Alami Untuk Fortifikasi Pangan. Jurnal Aplikasi Teknologi Pangan, 6(2).. https://doi.org/10.17728/jatp.205

Hasanah, M., Maharani, B., \& Munarsih, E. (2017). Daya Antioksidan Ekstrak dan Fraksi Daun Kopi Robusta (Coffea Robusta) Terhadap Pereaksi DPPH (2, 2difenil-1-pikrilhidrazil).

Indonesian Journal of

Pharmaceutical Science and Technology, 4(2), 42-49. https://doi.org/10.15416/ijpst.v4i2 .10456

Khotimah, K. (2014). Karakteristik Kimia Kopi Kawa Dari Berbagai Umur Helai Daun Kopi Yang Diproses Dengan Metode 
Jurdimas (Jurnal Pengabdian Kepada Masyarakat) Royal

Vol. 4 No. 2, Mei 2021, hlm. 141 - 146

ISSN 2614-7912 (Print)

DOI: https://doi.org/10.33330/jurdimas.v4i2.954

ISSN 2622-3813 (Online)

Available online at https://jurnal.stmikroyal.ac.id/index.php/jurdimas

Berbeda. Jurnal Teknologi Pudji, U \& Harta, M. (2015).

Pertanian, 9(1), 40-48.

Mayasari, N., \& Ani, H. M. (2016).

Pemberdayaan Perempuan

Melalui Pembuatan Kerupuk

Daun Kopi Pada Masyarakat Desa

Harjomulyo Kecamatan Silo

Kabupaten Jember. JURNAL

PENDIDIKAN EKONOMI:

Jurnal Ilmiah Ilmu Pendidikan,

Ilmu Ekonomi dan Ilmu Sosial,

Pemanfaatan Daun Kopi Sebagai

Pakan Ternak Hewan

Ruminansia. Balai Pengkajian Teknologi Pertanian Bengkulu.

Siringoringo, F. H. T., Lubis, Z., \& Nainggolan, R. J. (2012). Studi Pembuatan Teh Daun Kopi. Jurnal. Rekayasa Pangan dan Pert, 1(1), 1-5.

9(2). 